QE905

. $\mathrm{H} 3$

1913
Halle, T G

Some remarks on the classification of fossil plants 


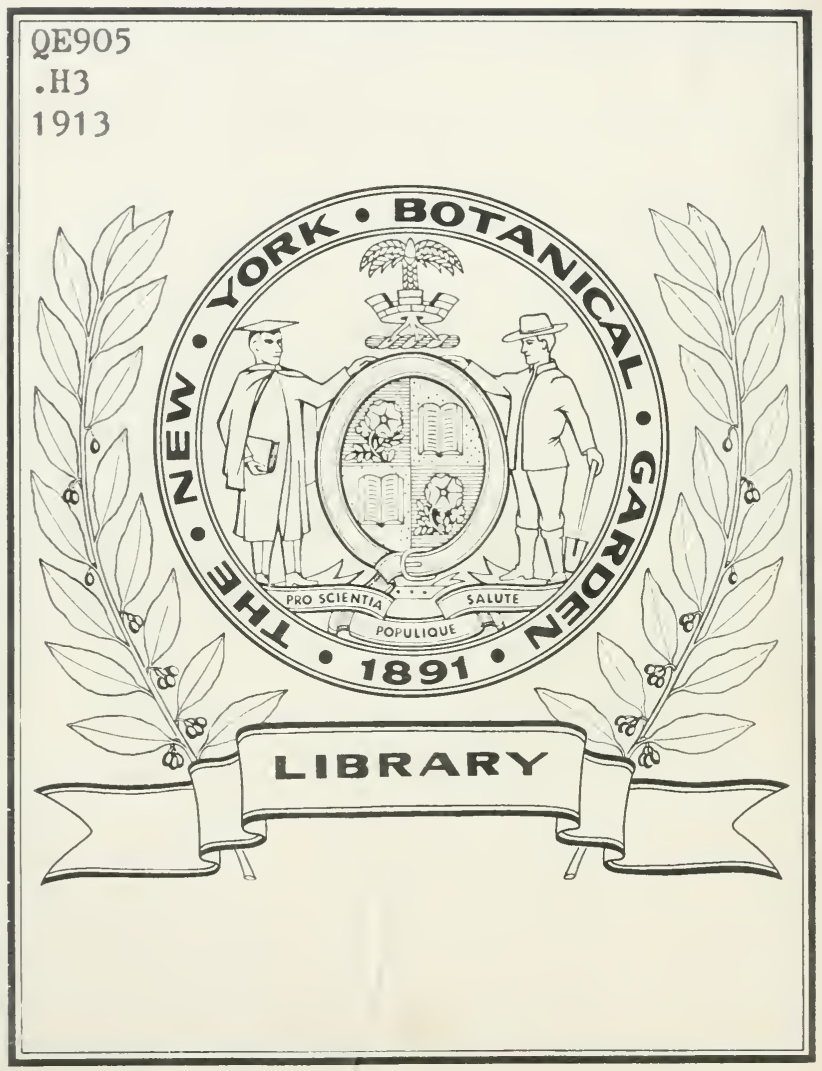






\section{T. G. HALLE}

\section{SOME REMARLS ON THE CLASSIFICATION OF FOSSIL PLAN'IS}


.13
1915 


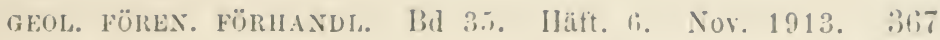

\title{
Some remarks on the classification of fossil plants.
}

\author{
$\mathrm{By}$ \\ 'T. G. HaLle. \\ (With Plates 9 and 10).
}

The difticulties attending the determination of fossil plant: are due, to a large extent, to the difference in the principles adopted by different writers in the delimitation of species. One of the most important points of dispute is whether, in doubtful cases, a broad or a narrow delimitation of species should be preferred. In a recent paper ${ }^{1}$ I have adrocated a narrow classification as being less apt to cause confusion in nomenclature and hasty conclusions in geological and palaengeographical matters. This course has later been criticizer by Professor A. C. Seward ${ }^{2}$ in his reriew of the paper mentioned. In ardition to his general reflections on the principles, Professor SEwan has also made several interesting remarks on the determinations of the Antarctic material. These remarks, which are closely connected with the general standpoint of Prof. SEWARD, call for an explanation from myself: and it would appear. too, that some points in my discussion of the principles would need emphasizing. It is naturally. hopeless to attempt a reconciliation of the two opposite principles, and a continued abstract discussion would serve no

1 HaLly. T. G. The Mesozoic Flora of Giaham Land. Wissensch. Ergebn. d. Srhwedischen siudpolar-Kxpedition 1901-1903. Bd. 3, Lief. 14, Stockholm 1913.

2. SEward, A. C. An extinet Antaretir flora. The New Phytologist. Vol. 12. Nos. 4 \& 5 , London 1913. 
useful purpose, but a few of the points in question may deserve some further consideration.

After quoting my opinion 'that it is a lesser evil to keep forms separated which are identical than to identify such as are distinct' Prof. Seward argues as an antithesis that it is a sound general principle 'to keep the mind open when there is no sufficient warrant for closing it'. It is a strange illustration of the difference in the conception of the problem that this very principle is the first and chief reason also for the exactly opposite course advocated by the present writer. Indeed, I believe that a brief consideration of the process of classification of fossil plants will show the narrow delimitation of species to represent the less committing way.

The individual specimens constituting the material of the palaeobotanist are grouped into species according to the degree of morphological similarity - very much in the same manner as in the classification of recent plants. There is the important difference, however, that the palaeobotanical specimens, in the overwhelming majority of cases, do not consist of individuals but only of portions of such. Therefore different organs of one individual may be referred to not only different species but different genera, this being the rule in many groups. And in cases of dimorphism, and even of great variation according to position on the plant, different specimens of one and the same kind of organ must often be described under different specific names though they really belong to the same species. These consequences, as every one knows, are unaroidable, being with necessity connected with the nature of the palaeobotanical material. And they cannot be eliminated by means of even the very broadest classification: there will always be cases of dimorphism in which it is impossible to trace the connection of the different types, and it is only exceptionally that the material to be described is sufficiently large to give a satisfactory idea of the range of rariation of the species. It follows, therefore, as a generally accepted fact, that the 
palaenbotanical species, especially in critical groups, is not it taxonomical unit in the same sense as speeies in the recont flora. The fiset of two groups of furms being described under different names does not imply. therefore, that they are necessarily distinet species but only that they cannot at present be proved to be identical. And this, it must be repeated, holds true even in the case of a broad classification. The process of classification of fossil plant-remains, in other words, must naturally be, on the whole, a synthetic one. It consists in grouping together specimens into form-units (artificial species) and piecing together such different parts and variations of a plant which have been described as artificial species, in order to get as accurate an idea as possible of the whole plant and its rariations (the natural species). The writer who prefers in a doubtful case to regard two similar forms as different species therefore only confesses his inability to establish an identification at the moment. He cautiously makes a pause in the synthetical process just because he belieres it to he a sound principle 'to keep the mind open when there is no sufficient warrant for closing it'.

The fact that the palaeobotanical species cannot be accepted as necessarily coinciding with the taxonomical may be used and has been used also as an argument for a broud classification. Since it is hopeless to strive at a natural delimitation of the species in all cases, it may be as well, it is argued, to use the specific name in a liberal sense, as a designation for a certain general type of the organ in question. In referring a questionable form to a certain palaeobotanical species, it is said, the former has not been stated actually to belong to the same natural species but only to show a certain resemblance of form. - This way of reasoning raises the question: 'what's in a name?' It cannot be helped that the palaeobotanical species to a large extent is treated as a natural one. An observation made on one or some few specimen of a palaeobotanical species is generally and naturally regarded 
as applicable to the whole species. Palaeobotany in general is, indeed, dependent on the possibility of so using, with all possible precaution, the palaeobotanical species, and the employment of specific designations mainly serves just to mark off such units. It is clear, therefore, that it must be an imperative demand to make these units as pure and unmixed as possible, so that a statement made in regard to some specimens of the species may with the greatest possible probability apply to all others designated by the same name. An example may serve to illustrate the dangers which, from this point of riew, attend a broad classification. We may imagine two sets of specimens of fern-leares, which an adherent of $a$ narrow classification would prefer to treat as two species but which, with a liberal delimitation of the species, are regarded as one. Specimens of the first of these sets are later found to have sporangia of, for instance, Osmundaceous type, and the result will be that the whole species will be stated to belong to that group. If then, after some time, specimens of the second set are found to belong to stems showing the anatomical features of the Marattiales, this character, by still regarding the species as a unit, will probably be applied to the species as a whole. The simple explanation may be that the name is used for two different natural species which may well belong to quite different groups. - It is clearly impossible to guard satisfactorily against this risk, eren with a narrow delimitation of species, and no doubt a large group of mistakes in palaeobotany is of this nature. But the use of specific names in a narrow sense will naturally tend to lessen this risk, whereas it hardly brings any other danger instear of it. In the case quoted, a mistake in this direction would only mean that the process of reconstruction of the particular species is delayed.

However one may look at the problem, it would appear that the use of specific names in a restricted sense would be less apt to cause confusion and mistakes. The most conspicuous objection. 
and the one most often expressed, is that this comrse involves the ereation of large numbers of transient specific names. due only to the 'mistakes' of the respertive authors. Having regarm to the limited nature of the palaeohotanical material, it need hardly be feared that the mere number of names will ("allse serious troubles. And there is this very important ditterence butwern the two cases: that a large number wi name- which are bound earh to a well-defined form, when tinally acknowledged as mere synonyms of a species bring much less confusion than a much smaller number of others which are used in a different sense by different authors and have been applied each to difterent species. 'The splitting up uf a vaguely defined species will always he found much more difficult than the joining of two narrowly defined forms to one species and the latter process only represents a natural stage in the progress of the classification of fossil plant-remain.

The phytogeographical side of the question has been fir the present sufficiently considered in my paper on the firdham l.and Flora. but it remains to add a few words in regard to its bearings on the stratigraphy. 'The importance of noting thr exact greological horizon on which a certain form oceurs ha- bren emphasized by Prof. NATuonst who gives, more"rलr, in his paper on the naming of dicotrledonou- leaves ${ }^{1}$ an expusition of many of the most important precautions to be comsidered in the classification of fossil plants. Fven a small difference between two forms may be of importance if each form is fomml to be restricted to a certain horizom. A coser attrution to this question than is generally bestower by palateobotanist- may often be found nseful in the delimitation of speries, and, rice iersa, may increase the geological importance of fosil plants. For this purpose, however, a narrow and carefiul delimitation of species is of paramount importaner. It is not intended to adrocate, with the abure remarks an

1 Nithorst. A G Veluer die Benennung fossiler likutylenblätler. Botanisches r'entralhlatt. Vul. 25.) 1siti. 
unrestricted use of new specific names. The aim must always be identification of those forms whose identity appears probable, and there is no loubt that with the increase of the material more and more 'species' will be found to be identical. Professor Seward, indeed, has clearly demonstrated, how a large material makes it possible to recognize as mere varieties forms which in case of a smaller number of specimens no doubt would be described as different species liuffordia Gorpperti of the Wealden-flora being a rery good instance. Only, it would appear that, when a less extensive material has to be described, a narrow delimitation wonld represent the more cautions course. The chief point is, of course, that the material should be sufficient for a description. It need not be large, since even a fairly small material may often be valuable, but it must be distinct and it must be well described and well figured. If these demands are met the species may be safely used as a basis for future discussion and thus answers its purpose, even if it is ultimately found to be a mere synonym.

After this abstract discussion the most important of Professor SEWARD's remarks on the determinations of the Antarctic plant-remains will be considered. These remarks, as already mentioned, for the most part are closely connected with the general standpoint of Professor SEward, and in such cases need no other discussion than the general exposition given above. The case of the only Equisetites-species of the Hope Bay Flora may be mentioned, however, as a good illustration. The close resemblance of some specimens of the Antarctic species E. approximatus Natir. to E. rajmalialensis Schmp. is noted in my memoir, with the remark that both forms may be identical. The Indian material of the species is very poor, however, consisting only of diaphragms, short pieces of stems and broken leaf-sheaths with teeth indistinct or wanting. ${ }^{1}$

${ }^{1}$ The specimens in Feistmantei's Pl. 35, figs. 3, 4, are probably inverted. 
I'arhyptris. And as Pachypteris is the older name and has been commonly used - also by Professor SEwARD in the 'Torkshire Flora - the name Dichopteris should be rejected. The unly plan to retain the genus Dichoptris is evidently to employ it in a very restricted sense for forms like those from the Italian Oolite, in which case my species of Sclropteris naturally cannot be included in it. Whether the renation and the peculiar habit of the Italian forms are sufficiently important characters to warrant this course, will not be discussed here, but it is certain that if Dichoptrins is used in the sense of Prof. SEwARD's ${ }^{1}$, it cannot be upheld but must be rejected in farour of Pachypteris. Whicherer course be followed. therefore, Dichopteris has only a secondary importance for the delimitation of the genera Pachyptris, Thinmfrltia and Scleropteris. 'This is the reason why I did not consider it in the discussion of these genera, jurlging it wiser to leave this question to somebody who could make a thorough comparative study of the Italian forms. - From what has been said abore regarding the relation of Pachypteris and Dichopteris, it will already be clear why $P$. dalmatica. which was probably correctly referred by $v$. Kenner to Pachypteris, has not been included in Dichopteris.

The nomenclature of Zamitean fronds. on which Professor SEWARD also remarks, is a very difficult matter, and as yet there hardly exists any method of classification which is not beset by difficulties. In my Graham Land paper I have discussed the relations of the genera Zamitrs. Ptilophyllum, and Otozamites: and Professor SEwARD remarks that I have used $Z$ amites 'for sereral forms which agree much more closely with Ptilophyllum fronds than with Zamites as usually employed'. This remark is interesting as it shows that Professor SEwARD accepts the generic name Ptilopliyllum. If both Zamitrs and Ptilopliyllum are employed it is naturally necessary to establish some agreement as to how the genera are

${ }^{1}$ Fossil Plants. Vol. 2, p. $55 \%$. 
to be delimited, in order that the names may not be nsed differently by different writers. I have tried to delimit I'tilophyllum by accepting FeIstuaxtel's definition which makes the downward trend of both pinna-edges at the hase the generic character. This is thus no new idea, the genus having been accepted in this sense al:o by other palaeubotanists atter the days of Ferstmaxtel. This character, it must he admitted, is not a very opportune one, since it is often only seen with difficulty, and it loes not mark off the genus very distinctly from all forms of Zumites, yet it seems to be the better one under the circumstances. As typical members of the genus Zumites may be regarded the species with large fronds of which the pinna-bases are distinctly rounded and characterized by a more or less marked callosity, Z. gigas being the best known representative of this group. The callosity cannot always be observed, however, and it: occurrence is generally not considered as a conditio sine qua non for a reference to Zumites. To the same genus are often referred smaller forms without callosity and with the pinna-basis very slightly rounded. As well-known representatives of this group of forms may be regarded the species of Zamites described by HExR ${ }^{1}$ from Greenland; and it was because of the resemblance of the Antarctic fronds to these Greenland forms that I referred the former to Zumites.

The difference between these two groups is in many cases obvious, and I have considered it in the paper quoted by distinguishing the two types as different sections of the genus. resp. Fuzumites and Subzumitrs. It may he that the latter section would be better designated by a new generic name, but I did not judge such a course sufficiently warranted. If, on the other hand, the woice is between inchuing these forms in \%amites and referring them to Ptilopluyllum, it would appear that the former genus is decidedly to be preferred.

1 Flora fossilis arrtica. Vol. 3, 1573, p. (3.) and foll., 1'ls. 14 and 15. 
It is true that Ptilophyllum as originally defined would embrace also fronds of the trpe in question. But, as in the case of Zumits and other old genera of Cycardophytean fronds, it has become necessary to substitute a more distinct definition for the original one: otherwise the genus would come into collision with other genera now commonly accepted. This has been done by Ferstuaxtel, whose definition of the genus seems to meet the most important demand to be made on a new definition of an old generic name, riz. to be based on the specimens for which the name was created. ${ }^{1}$ With exception of the numerous illustrations given by Feistmantel of the Indian species of Ptilophyllum, very few forms of that genus have been figured with due regard to the shape of the pinnabases. In addition to a reproduction (Pl. 9. fig. 1) of one of Feistuantel's figures of Ptilopliyllum acutifolium I have therefore given, in $\mathrm{Pl}$. 9, figs. 2-5, some photographs, in twice the natural size, of the pinna-bases of one of the English forms of the genus. This form, which is one of those commonly known among English palaeobotanists as Williamsonia pecten, is identical with Cycadites pectinoides PHILusps and should be named Ptilophlyllum pectinoides (PHILL.) Morr. It is seen from the figures to show the generic character of Ptilophyllum in FeIstMantel's sense by having an asymmetric pinna-base with both edges decurrent on the rachis. And it must be admitted that this is a very characteristic type of pinna-base which well deserves to be distinguished from that of typical Zamites species, such as Z. gigas.

In order to decide whether the Antarctic species of Zamitr's should be retained in that genus as a somewhat less typical group or included in Ptilopliyllum, they should be compared with typical specimens of these two genera. The text-figure:

1 Regarding the relation of FeIstMaxtel's definition to MoRRIs' type-specimens see HALLE, T. G.: some plant-bearing deposits in Patagonia and Tierra del Fuego and their floras. K. Sr. Vet. Akad. Handl., Bd 51, N:0 3. 1913, 1). 36 . 
1:2 and 1:3, pp. 57 and 5!4, resp., in my Mesozoic Florat of (iraham Land. the illustrations given by Herk (I. c.; Pl. 14; Pl. 1.). figs. 1-10) and especially the photographs in Pl. 10. figs. 1-6. of the present paper may be regarded as showing the typi"al shape of the pinna-base of the group in question. A romparison of these illustrations with those given in Pl. ! of - pecies of I'tilophlyllum cannot fail to show the difference. It is true that there may he many cases in which the distinctive characters cannot be discerned on account of the preservation, and also that intermediate forms exist; but the same will be found to be the ease with every other classification of these fromds. In a fairly large material of Jtilophyllum puctinoides from Whitby in Yorkshire I have found the generic character - in Ferstanatel's sense - to be present in all well preserved specimens. It is possible that in the larger collections in English museums there may be transitional forms; but as the proportion may be taken to be the same, these camnot be very numerous. - The same remark applies to the specimens of $P$. perten from the Middle Estuarine series and probably to the larger number of the forms referred, in Professur SEWARd's Jurassic Flora of the Yorkshire C'uast, to Williamsoniu pecten, not, however, to Otozamites Coldici Brax., (as figured by SAporta 1875), O. Mislopi Érstu.. (). angustifolins HeEr, etr., which are regarded in the same work as symonyms of Williamsonin preten, but which I should prefer to retain in the genus Otozrmites.

If forms like my Antarctic species of 'Zumites and the Greenland fronds described by HeEr under that name are referred to Ptilophyllum. the chief' character of that genus as defined by Fissmastel, could no longer be upheld. Instead there would he included in the same genus forms with two types of pinna-bases: the symmetrical base with slightly rounded corners of my Subzamitsisgroup and the asymetrical derurrent base of Itilophyllum in FEISTANTIL's sinse. It would be difficult to find any sutficient generic character 
of this wider genus Ptilophyllum. From the typical Zamites it would differ mainly by the less marked rounding of the basal corners and by the smaller size. The former distinction may be available in some cases but it would only be a diff'erence of degree, since even the very slightly rounded base of some of the Antarctic Zamites-forms belongs to the same type as that of $Z$. gigas and other typical species. If the specimens figured in $\mathrm{Pl}$. 10, fig. 7 , of this paper are compared with those in figures $1-6$ of the same plate, which show typical pinna-bases of different species. from Greenland and (xraham Land, referred by the present writer to Zamitr's, it will be difficult to find any difference sufficiently distinct to be expressed in a diagnosis. Indeed, it is not impossible that. with the classification adrocated by Professor SEWARD, the specimens in Pl. 10, fig. 7 , might be referred by some authors to Ptilophyllum. Yet this figure shows very typical specimens of Zamites gigas: only, these are reduced to the average size of the Ptilophyllum-fronds. It would appear from a consideration of this figure that the more stringent definition of Zamites is based to a great extent on the size. A difference of size may be a character of some importance; but it would not seem to be convenient to base on such a distinction a separation of two form-genera of a kind of fronds which show a rather great variation in size.

The choice is thus between distinguishing Zamites and Ptilophyllum in accordance with either the difference of shape of the pinna-base or the difference in the degree of rounding of the latter and in the size of the frond. As the latter course would involve both a mixing of two types with a different symmetry of the pinna-bases in one genus and a vaguer generic distinction between the genera, it does not appear to present any advantages.

It remains to discuss the question of the classification of sterile Coniferous shoots. I have created a new name, Elatoclactus, to be used for such sterile shoots of Conifers, whether 
of dorsiventral or of ralial habit, which cannot be included in any of the genera instituted for more peculiar forms. Professor SEwand, who admits that the nomenelature for these forms needs revision, remarks on the objection against the name, already disensised in my paper, that this generic term includes forms with leaves of the 'Tuxites type as well as branches with leaves like those of Sphenolepirlinm, Elatides, and other genera'. He proposes as an alternative plan 'to retain Tuxitrs in the wide sense in which it is used by most authors for twigs bearing linear and usually distichous leaves similar to those of Taus, certain species of I'odorupus, Seruoiu sempurrivens, and other recent Conifers, and to adopt the name Puyioplyyllum, for forms with radially disposed leaves like those of Elatides, sphrnolepidium, and Chrirol'pis.'

As to the use of Taxites for shoots of dorsiventral habit (with psemdo-distichous leaves) there is nothing to be said against this plan. BRongriart instituted the genus for forms with only a general resemblance in habit to the recent species of Taxus. He employed it, however, especially for 'Tertiary forms which possibly might be compared with the recent genus with greater probability than those from older formations. If this question is considered alone, it would seem convenient to retain T'uxitrs as adrocated by Professor SEWARD; and $I$ at first intended to employ the name in this sense.

In regard to the other group, shoots with radial symmetry, the question is more difficult. To use P'agiopluyllum in a wide sense, for this group, would not seem to be an improrement. P'upiryluyllum is usually employed as designation for a fairly natural form-genus, which undoubterlly should be retained tor forms with short and thick, often more or less triangular and strongly keeled leaves, the species figured by S.rporta (Plantes jurassiques, Vol. 3, 1884, Pls. 45-5.), under the name of Puchyphlyllum being good representatives of the group, in arldition to the type-species, I'ngiophyllum rerogrimum (LANDL. E Hutт.) Scrnex. It is true that there are transitions from this 
type to others - an example of this is the specimen of my Elatoclutus heterophylla figured in p. s5, text-fig. 18 b, of my Nesozoic Flora of Graham Land - but a definite separation of form-genera of sterile Conifers cannot be hoped for. Pagiofllyllum is thus hardly arailable as a designation for the larger group, and it is difficult to find any other existing name for this purpose. Elatirles would appear to be more appropriate than Pagiopliyllum, as the former genus represents a more general type with a less specialized kind of leaves, but since cone-bearing specimens of the genus have been described it would appear to be better to reserve the name for these. If no other existing name can be found for the group in question, there remains the possibility of creating a new one.

At first it seems no doubt to be the best to use two different form-genera for the sterile shoots of, so to say, the common, non-specialized Coniferous habit, and I originally intended to accept this plan in the description of the Antarctic material. In this material, however, as well as in most collections of any considerable number of fossil coniferous twigs, there are numerous specimens regarding which it is impossible to say whether the habit is radial or dorsiventral, $i$. $e$., to which of the two groups they should be referred. Moreover, there exist species which show both types in distinct development on one and the same specimen. Such, for instance. is the case with the dimorphic species described as Elatoclaclus heteropleylla, for which it would be difficult to find a suitable place with the classification proposed by Professor Sewaru. Naturally a classification should not be rejected because of the existence of a single case of dimorphism, with types of two form-genera in connection. But this kind of dimorphism is not rare among the Conifers, and it is known also in other fossil forms, for instance in Staclyyotaxus. In any case the fact that the generic name Elatocladus includes forms with leaves of the Taxites-type as well as branches with leaves 


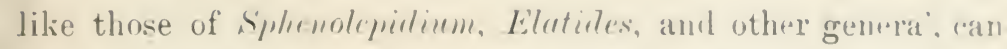
not be regarded on ipso as an objection agrainst it - noe. It $\mathrm{is}$, on the contrary, the ease that the artual necurrence in the same specimens of both these types implied the use of the same name for both of them. When we take into consideration the further fact that the two types are by no means distinct - the dorsiventrality of the Tuxites-shoot not being due to the arrangement of the leaves on the shoots, which is only preudo-nlistichous - there would appear to be good reasons for using only one name.

The most important objection against the use of Elutocludus as I have proposed it, and one of which I am well aware. is that it will have to include a large number of forms which really may be very different. But this is due to the nature of the material: when the latter does not show any sufficient gaps in the series of variations to permit the separation of different form-genera, the best thing seems to he to give way before this fact. The genus is in a high degree a provisional one and should be used only for forms which it is impossible to place in a better defined form-genus. Some such form-genera already exist, and many more will no doubt have to be distinguished in the future.

In bringing these remarks to a close it may be once more emphasized that it is not intended to adrocate that the determinations discussed here are necestarily right. All determinations of impressions of fossil plant must naturally be provisional and errors are inevitable, whichever methord of clasification is adopted. Of this, however, there can he no donbt, that the errors bring much less evil cousequences in the way of confusion and uncertainty if, within reasonable limits, the species are kept small and as strictly defined as possible. 


\section{Explanation of Plates.}

\section{Pl. 9.}

Fig. 1. Ptilophyllum acutifolium MoRr. Reproduction, in natural size, of the twice enlarged fig. $1 \mathrm{a}$, pl. 2, of Feistuantel: Ueber die indischen Cycadeengattungen Ptilophyllum und Jictyozamites, 1876.

Figs. 2-5. Ptilophyllum pectinoides (PHILL.) MORR. Portions of fronds from the Lower Estuarine Series of the Inferior Oolite, at Whitby, Yorkshire, showing the pinna-bases, $\times 2$.

\section{Pl. 10.}

Figs. 1-3. Zamites antarcticus HALLE, from the Jurassic of Hope Bay, Graham Land. Fig. 1, portion of the frond in texttig. $13 c$ of HaLLE: The Mesozoic Flora of Graham Land; nat. size; fig. 2, two pinna-bases from the same specimen, showing indications of callosity, $\times 5$; fig. 3 , pinna-bases of another specimen. $\times 5$.

Fig. 4. Zamites pusillus HaLle. Pinna-bases of the specimen in Pl. 7, fig. 12, and text-flg. $12 a$ of HALLE: The Mesozoic Flora of Graham Land, $\times 5$.

Figs. 5, 6. Zamites brevipennis HeER, from the Cretaceous of Western Greenland, $\times 2^{1}$. Fig. 5, part of the specimen in Pl. 15, fig. 10 ; fig. 6 , of the one in Pl. 15, fig. 9, of HeER: Die Kreide-Flora der arctischen Zone. Flora fossilis arctica. Tol. 3.

Fig. 7. Zamites gigas (Lindu. \& Hutt.) Morr. Large slab with several fronds from the Lover Estuarine series in the Inferior Oolite of Whitby in Yorkshire, reduced to ${ }^{1 / 4}$ of the nat. size.

All the specimens figured, with exception of the reproduction in PI. 1. fig. 1. are in the Palaeobotanical Department of the State Museum of Natural History at Stockholm. 
Geol. Fören:s Förhandl. Bd 35.
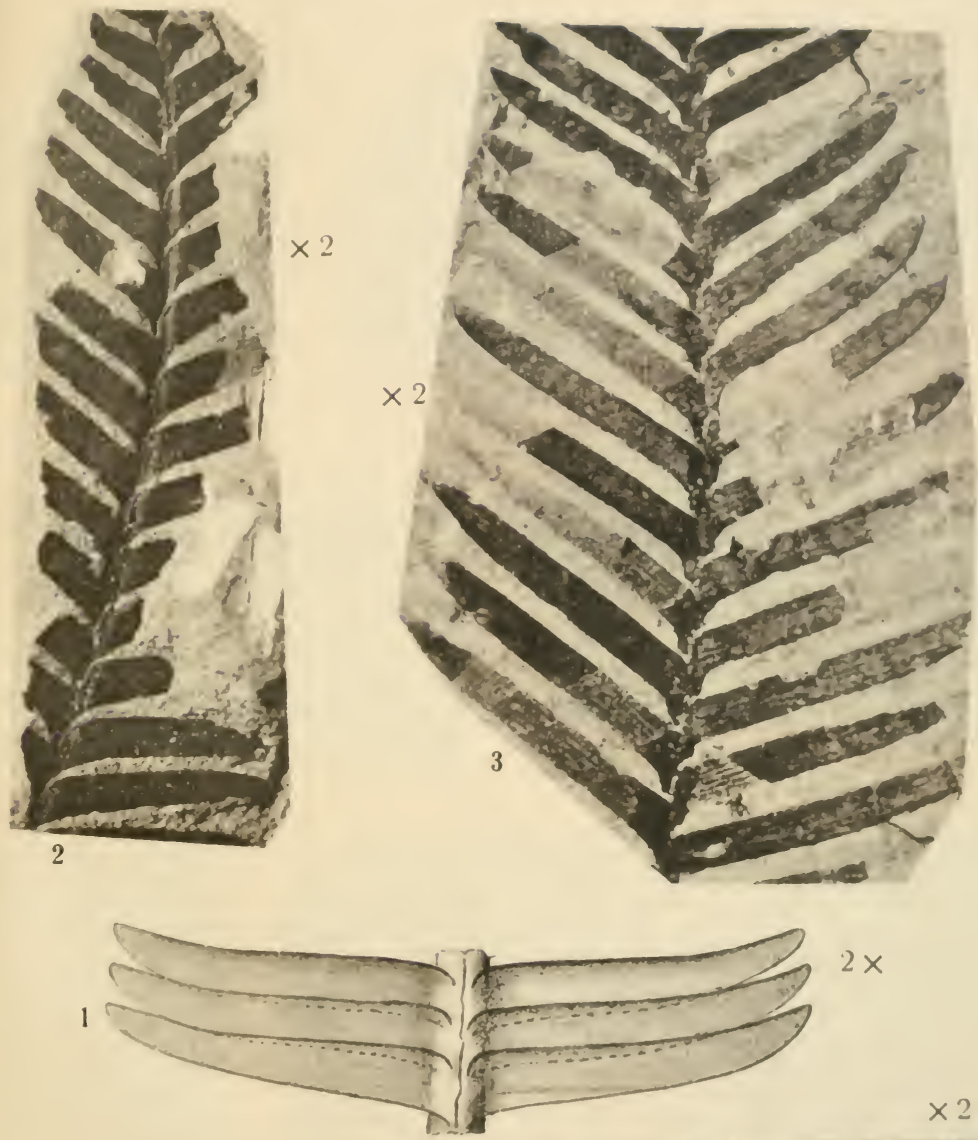

$\times 2$

$\times 2$

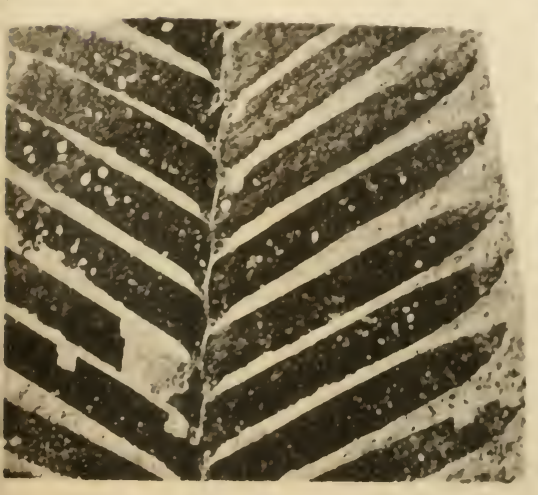

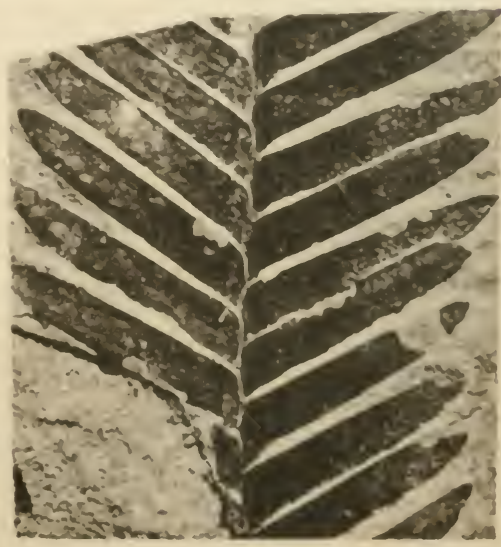

5

Cederquists Giraf. A.-B., Sthim. 




.

35185000922565 
